\title{
Impact of Agricultural Input Supply on Agricultural Growth in Nigeria
}

\section{*10PEYEMI, G; ${ }^{2}$ OLUSEGUN, SS; ${ }^{3}$ TAIWO, A; ${ }^{4}$ MOBOLAJI, AO}

\author{
${ }^{*}$ Department of Agricultural Economics and Extension, Faculty of Agriculture, ${ }^{2}$ Department of Economics, Kogi State University Anyigba \\ P.M.B. 1008, Anyigba, Kogi State, Nigeria \\ ${ }^{3}$ Division of Agricultural Colleges (KCA), Ahmadu Bello University, Zaria. Nigeria \\ ${ }^{4}$ Department of Agricultural Economics and Farm Management, Faculty of Agriculture, University of Ilorin, P.M.B 1515, Ilorin, Kwara \\ State, Nigeria \\ *Corresponding Author Email: opeyemi.g@ksu.edu.ng
}

\begin{abstract}
Improving the production capacity of agriculture in Nigeria through agricultural input supply is an important policy goal in a country where agriculture represents an important sector in the economy. The agricultural sector provides livelihood to a significant portion of Nigerian population, especially in rural areas, where poverty is more pronounced. Thus, a growing agricultural sector contributes to both overall growth and poverty alleviation. The study specifically examined the effects of agricultural input supply on agricultural growth in Nigeria from 1990 to 2017 . The objective of this study is to examine agricultural input supply in Nigeria and its implications on the growth of agricultural growth in Nigeria. The study used time series data covering 1986-2016 obtained from FAOSTAT, World Development Indicator and Central Bank of Nigeria data base. This study utilized Auto-Regressive Distributed Lag (ARDL) approach to investigate the variables. The finding of the study shows that there is co-integration between the variables. The result of the study shows that gross capital formation and Fertilizer supply to agriculture were significant in influencing agricultural growth in Nigeria with coefficient values of $(-0.002468)$, and $(0.001506)$, with P- values of $(0.0222)$ and (0.0171) respectively. Given the robust nature of the result, it is evident that agricultural input supply contributes in great measure to agricultural growth in Nigeria. The study then conclude that agricultural input is essential for the growth of agricultural sector in Nigeria and recommend that given the lean resources available to government, attention should be given to the inputs that contributes significantly to the growth of the sector.
\end{abstract}

\section{DOI: https://dx.doi.org/10.4314/jasem.v25i8.2}

Copyright: Copyright (C) 2021 Opeyemi et al. This is an open access article distributed under the Creative Commons Attribution License (CCL), which permits unrestricted use, distribution, and reproduction in any medium, provided the original work is properly cited.

Dates: Received: 10 May 2021; Revised: 28 June 2021; Accepted: 01 July 2021

Keywords: Agriculture, Input supply, Agricultural growth, Nigeria

The United Nations Organization (2008) estimated that the world as a whole, over $50 \%$ of the world population is engaged in agriculture or dependent of it for a living, this is a general description of the sector. Agriculture in Nigeria is made up of majorly forestry, livestock, fishing, food and cash crops. The country has a total land area of about 98.3 million hectares out of which 71.2 million hectares $(72.4 \%)$ are cultivable but only 34.2 million hectares $(34.8 \%)$ are under use (Daramola, 2004). The country is also largely endowed with abundant water resource, land supply, human and forestry resources needed by the sector. Agriculture being the most important sector in the Nigerian economy given its contribution, over the past several decades, to employment, foreign exchange, food supply, poverty reduction and its linkages with other sectors of the economy (Udah and Nwanchukwu, 2014), the necessities to improve in its growth and productivity are important for reducing poverty and achieving other development objectives. Agriculture holds the potential in accelerating the pace of economic growth and development of several countries of the world. It is the largest single employer and contributor to GDP in most of African countries.

Consequently, the sector employs about $51.3 \%$ of labour force in Nigeria and accounting for $70 \%$ of
GDP of the non-oil sector (National Bureau of Statistics, 2010). During the pre and immediate postIndependence era, the economy was predicated on agriculture. Agriculture contributed $90 \%$ of the Nation's GDP and foreign exchange before oil boom was discovered in Nigeria in early 1970s in commercial quantity and also provides subsistence for two third (2/3) of Nigerians who are low income earners in the economy (Yeomoni and Aladejana,2016). Given the critical role occupied by agriculture in Nigerian economy, Ikala (2010) has describe that agriculture is the profession of majority of humans. Oji-Okoro (2011), stated that agricultural sector is the largest sector in the Nigerian economy with its dominant share of the GDP, employment of more than $70 \%$ of the active labour force and the generation of about $88 \%$ of non-oil foreign exchange earnings. Given the critical role occupied by agriculture in Nigerian economy, Iganiga and Unemhilin (2011) noted that stagnation in agriculture is the principal explanation for poor economic performance, while rising agricultural productivity has been the most important concomitant of successful industrialization (Iganiga and Unemhilin,2011).

Generally, the sector contributes to the development of an economy in four major ways-product contribution, 
factor contribution, market contribution and foreign exchange contribution. Notwithstanding the enviable position of the oil sector in the Nigerian economy over the past three decades, the agricultural sector is arguably the most important sector of the economy. Agriculture's contribution to the Gross Domestic product (GDP) has remained stable at be-tween 30 and 42 percent, and employs 65 percent, of the labour force in Nigeria (Emeka 2007). Agriculture has often been touted crucial in the economic development of most third world countries. Recent researches on the causes of development and underdevelopment have identified agriculture as key to the economic emancipation of ailing states. However, how the country go about the contest for economic development without agriculture as weapon, and how it hope to win, indeed, remains a moot issue (Dim and Ezenekwe, 2013).

Given the foregoing, Food and Agricultural Organization (2014), reported that the sector faces many challenges, notably an outdated land tenure system that constrains access to land (1.8 ha/farming household), a very low level of irrigation development (less than 1 percent of cropped land under irrigation), limited adoption of research findings and technologies, high cost of farm inputs, poor access to credit, inefficient fertilizer procurement and distribution, inadequate storage facilities and poor access to markets have all combined to keep agricultural productivity low with high postharvest losses and waste. Since the most effective way to improve the lives of millions in poverty is to support agriculture.

Given that most of the country's poor are farmers, and those who are not spend much of their income on food. Hence, agricultural growth has great potential for transforming the country's economy with implication on job creation, raise incomes, reduce malnutrition, and kick-start the economy on a path to middle-income growth. Several factors have been identified to enhance or retard growth in the agricultural sector. These factors include education infrastructure (Gopinath and Roe 1997; Yee et al., 2000 and Venk Atachalam 2003) and inflation (Gokal and Hanif 2004). Others are credit to the sector and rainfall.

Empirical studies that combined institutional, infrastructural, and Technological factors in their analysis of the determinants of agricultural growth are few. This study seek to fill the gap in literature by using variables from institutional, infrastructural, and Technological variables in its analysis. This is necessary because, the relationship between government policy and agricultural supply requires empirical evidences on different categories of agricultural input supply. Further, approaches taken to grow agricultural sector are shaped by the prescriptions and outcomes of empirical research of this nature. Thus, this study seek to examine the effects of agricultural input supply on agricultural growth in
Nigeria between 1991 and 2017 using stationary, ARDL Bound test and Auto Regressive Distributed Lag (ARDL) bounds analysis. Some of the questions raised include what are the significant effects of agrarian input supply on agricultural growth in Nigeria? What is the relevance of agricultural input supply on agricultural growth?

A study of this nature becomes very necessary, recognizing that government policy is one of the shortest and critical ways to influence agricultural growth. The study seeks to provide clear recommendations based on findings capable of shifting agricultural production in some way, whether this means policies to enhance growth in agricultural sector or contribute in some ways to literature on the subject matter. Findings from the study are expected to assist researchers, policy makers and relevant government agencies in their research work, planning, policy making, that can help in reducing food insecurity gap and more importantly, achieving a food secured nation. Information from this study address major determinants of agricultural growth, thus, providing policy makers with abound knowledge on agricultural growth and appropriate way of finding where policies can rightly respond to agricultural issues.

\section{MATERIALS AND METHODS}

One econometric models was formulated to achieve the objectives of this study. The model evaluated the effects of agricultural input supply on agricultural growth measured by the contribution of agriculture to GDP in Nigeria.

$$
\begin{aligned}
\mathrm{AGO}=\beta_{0}+\beta_{1} \mathrm{AGL}_{\mathrm{t}}+\beta_{2} \mathrm{AC}_{\mathrm{t}}+\beta_{3} \mathrm{ELECT}_{\mathrm{t}}+\beta_{4} \mathrm{FDI}_{\mathrm{t}} \\
+\beta_{5} \mathrm{GFCF}_{\mathrm{t}}+\beta_{6} \mathrm{FERT}_{\mathrm{t}}+\beta_{7} \mathrm{PEST}_{\mathrm{t}} \\
+\mathrm{u}_{\mathrm{t}}
\end{aligned}
$$

Where, $\beta_{0}=$ The intercept $/$ mean of the equation; AGO $=$ Agricultural contribution to Gross Domestic Products; AGL = Agricultural Land (hectares); $\mathrm{AC}=$ Agricultural Commercial Bank credit to agricultural sector (Naira); ELECT = Electricity energy (Megawatt); FDI = Foreign Direct Investment to agricultural sector (Naira); GFCF = Gross Fixed Capital Formation (Naira); FERT = Fertilizer imported into Nigeria (Naira); PEST = Pesticides imported into the country (Naira); $\beta 1$ to $\beta 7=$ The coefficients of the variables to be estimated; $\mu=$ The error term

This aspect deals with the provision of information on the variables included in the model for the data analysis. It provides definition of the variables, the proxies for the variables and the justification for their inclusion in the models. The dependent variables used for the study were the total agricultural contribution to GDP. 


\begin{tabular}{lll}
\multicolumn{2}{l}{ Table 1: The independent variables are those factors or policies influencing agricultural production output in Nigeria. } \\
\hline $\begin{array}{l}\text { Independent } \\
\text { variable }\end{array}$ & Definition & Sources \\
AGO & Contribution of agriculture to GDP. & CBN \\
AGL & Agricultural land cultivated yearly & CBN \\
AC & Agricultural credit granted by commercial banks in Nigeria yearly. & CBN \\
ELECT & The quantity of electricity generated yearly & World Development Indicator. \\
FDI & Volume of foreign direct investment & FAOSTAT \\
GFCF & Value of machineries imported in the country & World Development Indicator \\
FERT & Nitrogen fertilizer imported into the country & FAOSTAT \\
PEST & Agrochemicals imported into the country & FAOSTAT \\
\hline & & Source Authors Compilation, (2018)
\end{tabular}

Source Authors Compilation, (2018)

This study used an annual time series data which covered a period of 30 years, 1990-2017. The data were secondary in nature and were sourced from FAOSTAT, World Development Indicator data and Central Bank of Nigeria data base.

A unit root test was conducted on the time series data to ensure the stationarity of the data used. ARDL Bound test among the dependent variables. The validity and reliability of secondary data used is assured because they are extracted from the FAOSTAT, Central Bank of Nigeria and World Bank data base.

The estimation techniques used for this study were unit root test to ensure the stationarity of the variables used, ARDL Bound Test and ARDL Bounds Co-integration was employed. The analysis was conducted through EViews 10.0 software application package.

\section{RESULTS AND DISCUSSIONS}

This test is conducted to determine the order of integration of the variables employed in the study using the Augmented Dickey-Fuller (ADF) stationarity test. The table 2 below is the results of the ADF stationarity test. From Table 2 above using Augmented Dickey Fuller unit root test, it can be seen that Agric Land, Credit to Agric, Electricity, Gross Fixed Capital Formation, Fertilizer and Pesticide were stationary at first difference while Agicultural Output, Foreign Direct Investment(Agriculture) were stationary at second difference. The stationarity was determined at $5 \%$ level of significance.

\begin{tabular}{lccccc}
\multicolumn{2}{c}{ Table 2: ADF Stationarity Test between Agricultural Output and its determinants } \\
\hline \multicolumn{1}{c}{ Variables } & ADF Statistics & $\begin{array}{l}\text { Critical } \\
\text { Value at 5\% }\end{array}$ & $\begin{array}{l}\text { Order of } \\
\text { Integration }\end{array}$ & Probability & Decision \\
\hline Ago & -6.776169 & -3.012363 & $\mathrm{I}(2)$ & 0.0000 & Stationary \\
Agric Land & -3.990580 & -3.004861 & $\mathrm{I}(1)$ & 0.0061 & Stationary \\
Credit to Agric & -5.397114 & -3.004861 & $\mathrm{I}(1)$ & 0.0003 & Stationary \\
Electricity & -5.473951 & -3.020686 & $\mathrm{I}(1)$ & 0.0003 & Stationary \\
Foreign Direct Investment & -8.546209 & -3.020686 & $\mathrm{I}(2)$ & 0.0000 & Stationary \\
GFCF & -3.827436 & -3.020686 & $\mathrm{I}(1)$ & 0.0096 & Stationary \\
Fertilizer & -12.52714 & -3.004861 & $\mathrm{I}(1)$ & 0.0000 & Stationary \\
Pesticide & -4.585069 & -3.029970 & $\mathrm{I}(1)$ & 0.0021 & Stationary \\
\hline \multicolumn{5}{c}{ Source: Researchers Computations, 2020 Using E-views 10} &
\end{tabular}

Source: Researchers Computations, 2020 Using E-views 10

\begin{tabular}{lllll}
\multicolumn{5}{c}{ Table 3: ARDL Bound Test } \\
\hline Test Statistics \\
\hline F-Statistics \\
Critical Value Bounds \\
Significance & $10 \%$ & $5 \%$ & $2.5 \%$ & $1 \%$ \\
I(0) & 1.92 & 2.17 & 2.43 & 2.73 \\
I(1) & 2.89 & 3.21 & 3.51 & 3.90 \\
\hline Source: Researchers Computations, & 2020 & Using E-views 10
\end{tabular}

Given the result of the unit root tests which shows that all the variables are not stationary at level, but instead a combination of I (1) and I (0) series, therefore the most appropriate test of co- integration is the Autoregressive Distributed Lag (ARDL) Bound Test of co-integration. This is employed for the model in this study. The null hypothesis indicates that, there is no long-run relationship between the dependent and independent variables. The decision rule is to reject null hypothesis when F-statistics of the test is greater than the Critical Value of Upper Bound at a chosen level of significance i.e ( $5 \%$ for this study). On the other hand, the null hypothesis is accepted when the F- statistics is less than that of the Critical Value of the Lower Bound. When the F-statìstics falls between the upper and the lower bound, it then means that the test is considered inconclusive.

However, the result of the test above indicates that the F-statistics of the variables is 13.24389 with $5 \%$ Critical Values of the Lower Bound 3.21 and the Upper 2.17 respectively. This shows that the Fstatistics 9243.374 is greater than the Critical Values of both the lower and the Upper Bounds in the model. This implies the rejection of null hypothesis, while alternative hypothesis is accepted. Hence, the test 
shows that there is co-integration (long-run relationship) between the Agricultural land, credit to Farmers, pesticide, foreign direct investment on agriculture, Electricity, fertilizer, Gross Fixed Capital Formation and Agricultural Output in Nigeria.Auto Regressive Distributed Lag (ARDL) bounds analysis is the estimation procedure that involves test of long run relationship interactions among the variables of the study. ARDL model was developed by Pesaran and
Shin (1999), primarily to examine the short run and long run coefficients of the underlying variables. ARDL model does not need all variables to be integrated of the same order before it can be utilized in an investigation. The model can be used even when the variables are fractionally integrated or with combined integrated of order one and order zero. The model is relatively more efficient even when the data size is very finite small.

Table 4: ARDL Regression Result

\begin{tabular}{|c|c|c|c|c|}
\hline \multicolumn{5}{|c|}{$\begin{array}{l}\text { DEPENDENT VARIABLE }=\text { LOGAGO } \\
\text { LOGAGO }=\beta_{0}+\beta_{1} \text { LOGFDI }+\beta_{2} \text { LOGELC }\end{array}$} \\
\hline VARIABLES & COEFFICIENT & STD. ERROR & T-STAT. & PROB.VALUES \\
\hline AGRIC_OUTPUT(-1) & 0.992709 & 0.119372 & 8.316083 & 0.0000 \\
\hline FDI & 0.000266 & 0.001366 & 0.195068 & 0.8481 \\
\hline ELECTRICITY & 0.006182 & 0.012864 & 0.480549 & 0.6383 \\
\hline CREDIT_TO_AGRIC & -0.001265 & 0.001487 & -0.850836 & 0.4092 \\
\hline AGRIC_LAND & -0.010366 & 0.030871 & -0.335777 & 0.7420 \\
\hline GFCF & -0.002468 & 0.000960 & -2.570438 & 0.0222 \\
\hline NITROGEN & 0.001506 & 0.000557 & 2.705912 & 0.0171 \\
\hline PESTICIDE & 0.001660 & 0.001056 & 1.572312 & 0.1382 \\
\hline $\mathrm{C}$ & 0.046267 & 0.198745 & 0.232796 & 0.8193 \\
\hline \multicolumn{5}{|c|}{$\begin{array}{l}\mathrm{R}^{2}=0.992876 ; \text { ADJUSTED } \mathrm{R}^{2}=0.988806 ; \text { F-statistic }=243.9115 ; \text { Prob }(\text { F-statistic })=0.000000 \\
1.865012\end{array}$} \\
\hline
\end{tabular}

Table 4 above is an illustration of the results of the ARDL bounds co-integration test between AGO and its determinants. From the summary of the estimated results above, it is clear that Agricultural Output (AGO) is the dependent variable, while Foreign Direct Investment on Agric, Electricity, Credit to Agriculture, Agricultural land use in hectares, Gross Fixed Capital Formation, Fertilizer and Pesticide were the independent variables. The coefficient of the dependent variable when all the independent variable is held constant is given as 0.046267 , this indicates a positive and insignificant relationship between the intercept $\left(\beta_{0}\right)$ and Agricultural Output. The regression coefficient of Foreign Direct Investment FDI is 0.000266. It shows that if Foreign Direct Investment increases by 1, Agricultural Output increases by 0.000266 ; this is positive indicating that there is a positive relationship between Agricultural Output and Foreign Direct Investment. It is statistically not significant at 1 percent, 5 percent and 10 percent level of significance. The regression coefficient of Electricity is 0.006182 . It shows that if Electricity increases by 1 percent, Gross Domestic Product increases by 0.006182 percent. It is positive indicating that there is a positive relationship between Electricity and Gross Domestic Product. It is statistically not significant at 5 percent and 10 percent levels of significance. The regression coefficient of Credit to Agricultural sector is -0.001265 . It shows that if Credit to Agricultural sector increases by 1 percent, Agricultural Output decreases by -0.001265 percent. It is negative indicating that there is a negative relationship between Credit to Agricultural sector and Agricultural Output. It is statistically significant at 5 percent and 10 percent levels of significance. The regression coefficient of Agricultural land use is -
0.010366. It shows that if Agric Land Use increases by 1 percent, Agricultural Output increases by -0.010366 percent. It is positive indicating that there is a positive relationship between Agricultural land use and Agricultural output. It is statistically not significant at 1 percent, 5 percent and 10 percent levels of significance. The regression coefficient of Gross Fixed Capital Formation is -0.002468 . It shows that if Gross Fixed Capital Formation increases by 1 percent, Agricultural Output decreases by -0.002468 percent. It is negative indicating that there is a negative relationship between Gross Fixed Capital Formation and Agricultural Output. It is statistically significant at 5 percent and 10 percent levels of significance. The regression coefficient of Nitrogen is 0.001506 . It shows that if Nitrogen increases by 1 percent, Agricultural Output increases by 0.001506 percent. It is positive indicating that there is a positive relationship between Nitrogen and Agricultural Output. It is statistically significant at 5 percent and 10 percent levels of significance. The regression coefficient of Pesticide is 0.001660 . It shows that if Pesticide increases by 1 percent, Agricultural Output increases by 0.001660 percent. It is positive indicating that there is a positive relationship between Pesticide and Agricultural Output. It is statistically not significant at 1 percent and 5 percent levels of significance but significant at 10 percent level of significance. The coefficient of determination is 0.992876. it shows that 99 percent variation in Agricultural Output in Nigeria is caused by the variations in Agricultural land, credit to Farmers, pesticide, foreign direct investment on agriculture, Electricity, Fertilizers, Gross Fixed Capital Formation. It means that only 1 percent of the changes in Agricultural Output in Nigeria is caused by other 
factors that are not included in the model. More so, result showed that F-statistic is 243.9115 while the probability (F-statistic) is 0.000000 which indicate that the combined influence of the exogenous variables on the dependent variable is statistically significant. The results also showed that coefficient of determination, $\mathrm{R}^{2}$ is 0.992876 . The result indicated that $99.3 \%$ of the variations in the dependent variable Agricultural Output are explained by the exogenous variables (Foreign Direct Investment on Agric, Electricity, Credit to Agriculture, Agricultural land use in hectares Gross Fixed Capital Formation, Fertilizer and Pesticide) while the remaining $0.7 \%$ is attributed to other factors not included in the model. Furthermore, the results revealed Durbin Watson (DW) statistic of 1.865012, which implies that serial correlation is not found in the model. To further confirm this claim, Breusch-Godfrey serial Correlation LM test was carried out, and the results showed Observed Rsquared value of 2.523340 while the Prob.Chi-Square is 0.2832. Since the Prob.Chi-Square is greater than $5 \%$ critical value, the study accepts the early assertion and concludes that serial correlation does not exist in the model. Furthermore, the study applied Ramsey RESET to test for the model specification. From the results, the t-statistic and F-statistic values are 1.619235 and 2.621922 with the associated p-value being 0.1980 . The p-value of 0.1294 is greater than $5 \%$ critical value; hence, the study concludes that the model is well specified. More so, the presence of homoscedasticity was tested by employing heteroscedasticity test: ARCH approach. The results showed evidence of homoscedastic in the model.

Policy Implications of the Result: The study investigated the influence of agricultural input supply on Agricultural Output in Nigeria for the period 19912017. The result of the ARDL bound test indicated the evidence of a long run relationship among the variables. Thus, it is estimated on average that $1 \%$ increase in Foreign Direct Investment to Agriculture will lead to $0.0266 \%$ increase on Agricultural Output in Nigeria, $1 \%$ Increase in Electricity will lead to $0.6182 \%$ increase on Agricultural Output in Nigeria, $1 \%$ Increase in credit to Agriculture will lead to $0.1265 \%$ decrease on Agricultural Output in Nigeria, $1 \%$ Increase in Agricultural Land will lead to $1.0366 \%$ decrease on Agricultural Output in Nigeria, $1 \%$ Increase in Gross Fixed Capital Formation will lead to $0.2468 \%$ decrease on Agricultural Output in Nigeria, $1 \%$ Increase in Fertilizers will lead to $0.1506 \%$ increase on Agricultural Output in Nigeria, $1 \%$ Increase in Pesticide will lead to $0.05 \%$ increase on Agricultural Output in the Nigeria economy.

Conclusion: The results showed that Agricultural land (in hectares), Credit to Agriculture, Electricity, Gross Fixed Capital Formation, Fertilizers and Pesticide were stationary at first difference. The ARDL Bound test results indicated long run relationships exist among the variables of the study. The result reveals fertilizer had positive and significant influence on Agricultural Output. Also, GFCF had significant influence on Agricultural Output. The study then conclude that agricultural input is essential for the growth of agricultural sector in Nigeria and recommend that given the lean resources available to government, attention should be given to the inputs that contributes significantly to the growth of the sector.

\section{REFERENCES}

Ayeomoni, O; Aladejana, SA. (2016). Agricultural Credit and Economic Growth Nexus. Evidence from Nigeria, Inter. J. Acad. Res. Acct. Fin. Manage. Sci. 6(2), 146-158.

Daramola, AG, (2004). "Competitiveness of Nigeria Agriculture in a Global Economy: Any Dividends of Democracy?", Inaugural Lecture Series 36 delivered at the Federal University of Technology, Akure, 2nd March, 2004, pp: 1.

Dim Chukwuma; Ezenekwe U. (2013). Does Agriculture Matter for Economic Development? Empirical Evidence from Nigeria. J. Fin. Econ. 1 (1) 61-77.

Emeka OM., (2007). Improving the agricultural sector toward economic development and poverty reduction in Nigeria. CBN Bull. 4: 23-56.

Food and Agricultural Organization (2014). Nigeria at a glance. Retrieved from http://www.fao.org/nigeria/fao-in-nigeria/nigeriaat-a-glance/en/

Gokal V, Hanif S (2004). Relationship between inflation and economic growth. Working Paper 2004 of Development Reserve Bank of Fiji, 36: 5867.

Iganiga BO; Unemhilin DO (2011). The Impact of Federal Government Agricultural Expenditure on Agricultural Output in Nigeria, Kamla-Raj 2011J Economics, 2(2): 81-88.

Ikala, PA (2010). Impact of public agriculture expenditure on agricultural output and economic growth: (1978-2007). An Unpublished thesis of the Caritas University, Amorji-Nike; Emene Enugu.

Nigeria Bureau of Statistics (2010). Nigeria Poverty Profile 2010. Yearly report

Oji-Okoro, I (2011). Analysis of the contribution of agricultural sector on the Nigerian economic development. World Rev. Bus. Res. 1(1), 191-200. 
Pesaran, MH; Shin, Y (1999). An autoregressive distributed lag modelling approach to cointegration analysis. Chapter 11 in S. Strom (ed.), Econometrics and Economic Theory in the 20th Century: The Ragnar Frisch Centennial Symposium. Cambridge University Press, Cambridge. (Discussion Paper version).
Udah, SC; Nwachukwu, IN (2104). Determinant of GDP agricultural growth in Nigeria. Inter. J. Agric. Res. Rev. 3(3). 184-190.

Yee, J; Huffman, W; Newton D (2002). Sources of agricultural producing growth at the state level. NC-208 Meeting on Agricultural Productivity Data. Methods and Measures. Washington D.C.: University Press. 